\title{
Effect of gel polymer electrolyte based on polyvinyl alcohol/polyethylene oxide blend and sodium salts on the performance of solid-state supercapacitor
}

\author{
HOP TRAN THI THANH, PHUOC ANH LE, MAI DANG THI, TUAN LE QUANG \\ and TUNG NGO TRINH* \\ Institute of Chemistry, Vietnam Academy of Science and Technology (VAST), Hanoi, Vietnam \\ *Author for correspondence (ngotrinhtung@gmail.com)
}

MS received 18 October 2017; accepted 15 January 2018; published online 3 December 2018

\begin{abstract}
In this work, the effect of gel polymer electrolytes (GPE) containing polyvinyl alcohol/polyethylene oxide $(90 / 10$, wt $\%)$ blend and different contents of sodium salt mixture (sodium acetate $\left(\mathrm{CH}_{3} \mathrm{COONa}\right) /$ sodium sulphate $\left.\left(\mathrm{Na}_{2} \mathrm{SO}_{4}\right)=50 / 50 \mathrm{wt} \%\right)$ on the performance of solid-state supercapacitor was investigated. The active electrode of the solid-state supercapacitor was made from graphene nanoplatelets and carbon black. The results indicate that the sodium salt mixtures were easily mixed in polymer blend gel to make excellent GPE with large concentration of ionic liquid. At the sodium salt mixture content of 30\%, the solid-state supercapacitor showed the best performance of electrode-specific capacitance of $93.768 \mathrm{~F} \mathrm{~g}^{-1}$ at current density of $1 \mathrm{~A} \mathrm{~g}^{-1}$, energy density of $3.25 \mathrm{Wh} \mathrm{kg}^{-1}$ and power density of $586.166 \mathrm{~W} \mathrm{~kg}^{-1}$. These results highly recommend the good potential of GPE for developing solid-state supercapacitor in the future.
\end{abstract}

Keywords. Solid-state supercapacitor; gel polymer electrolytes; polymer blend; sodium salt.

\section{Introduction}

Solid-state supercapacitors have recently attracted much research attention in modern technology because they provide many advantages than the original capacitors, such as higher charge-discharge, avoid leaking electrolyte liquid and good mechanical stability. To further improve the specific capacitance and energy density, many gel polymer electrolytes (GPE) were developed by using new polymer or polymer blends as host polymer frame of the electrolyte to avoid the leaking of liquid. Additionally, there are many different types of metal salt systems added into polymer to provide higher conductive ionics, such as lithium salts $\left(\mathrm{Li}_{2} \mathrm{SO}_{4}, \mathrm{LiCl}, \mathrm{LiClO}_{4}, \mathrm{LiBr}, \mathrm{LiTFSI}\right)$, sodium salts $\left(\mathrm{Na}_{2} \mathrm{SO}_{4}, \mathrm{NaClO}_{4}, \mathrm{NaBr}, \mathrm{NaI}, \mathrm{CH}_{3} \mathrm{COONa}\right)$, which were studied widely [1-6].

Polyvinyl alcohol (PVA) is widely used in GPE for supercapacitors. The main advantages of PVA in GPE are their ability to solvate large amount of alkali-metal salts, their high ionic conductivities below the glass temperature, high mechanical strength and reduction of electrolyte leakage risk. However, GPE using PVA, faced a problem of low ductility as well as inherently brittle and easily precipitate due to the breakage of $\mathrm{OH}$ bonding in the presence of organic and inorganic ions, such as $\mathrm{CH}_{3} \mathrm{COO}^{-}, \mathrm{Na}^{+}$and $\mathrm{K}^{+}$[7-12]. To fill up this drawback, the appearance of polyethylene oxide (PEO) as doping mediator is considered good idea to make strong GPE. Both PVA and PEO are non-toxic, water-soluble polymer, low-cost, which are used widely in industry. The blending of PVA-PEO provides hydroxyl group and hydrogen bond and good charge storage capability [13-15].

In this paper, a solid-state supercapacitors with the GPE consisting of PVA/PEO blend as polymer host frame and mixture of sodium acetate $\left(\mathrm{CH}_{3} \mathrm{COONa}\right)$ and sodium sulphate $\left(\mathrm{Na}_{2} \mathrm{SO}_{4}\right)$ as ionic liquid were fabricated and investigated. In the best of our knowledge, this is the first report on the use of two sodium salts as ionic liquid by the fabrication of solid-state supercapacitor. The two sodium salts could provide different sizes of anions, which could diffuse deeply in the graphene/carbon black electrode network. Thus, the use of sodium salt mixture will increase the ionic conductivity of the GPE and also will improve the specific capacitance as well as the energy storage. In addition, the partly replacement of $\mathrm{Na}_{2} \mathrm{SO}_{4}$ by $\mathrm{CH}_{3} \mathrm{COONa}$ is desired for environmental protection [18]. All electrochemical properties of the solid-state supercapacitors were investigated via three electrodes testing cell to determine their performance.

\section{Experimental}

\subsection{Materials}

Poly(vinyl alcohol) (PVA, 95\% hydrolysed, average $M_{\mathrm{w}}=$ 95, $000 \mathrm{~g} \mathrm{~mol}^{-1}$ ) was from Across company. Poly(vinylidene fluoride) (PVDF, $M_{\mathrm{w}}=534,000 \mathrm{~g} \mathrm{~mol}^{-1}$ ), $\mathrm{CH}_{3} \mathrm{COONa}$, 
Table 1. Compositions of gel polymer electrolytes.

\begin{tabular}{lcc}
\hline Sample name & $\begin{array}{c}\text { PVA/PEO (9:1) } \\
\text { blend (wt } \%)\end{array}$ & $\begin{array}{r}\mathrm{CH}_{3} \mathrm{COONa} / \mathrm{Na}_{2} \mathrm{SO}_{4} \\
(1: 1) \text { mixture (wt } \%)\end{array}$ \\
\hline PCN1 & 90 & 10 \\
PCN2 & 80 & 20 \\
PCN3 & 70 & 30 \\
\hline
\end{tabular}

sodium sulphate tetrahydrate $\left(\mathrm{Na}_{2} \mathrm{SO}_{4} \cdot 4 \mathrm{H}_{2} \mathrm{O}\right)$ were from Sigma Aldrich. Poly(ethylene oxide) $\left(\mathrm{PEO}, M_{\mathrm{w}}=\right.$ 1,000,000 $\left.\mathrm{g} \mathrm{mol}^{-1}\right)$, 1-methyl-2-pyrrolidinone $\left(\mathrm{C}_{5} \mathrm{H}_{9} \mathrm{NO}\right)$ (NMP) and carbon black acetylene (100\% compressed) were purchased from Alfa Aesar company. Graphene nanoplatelets (6-8 $\mathrm{nm}$ thick, $\times 5 \mu \mathrm{m}$ wide) were from Strem Chemicals.

\subsection{Preparation of electrodes}

Graphene nanoplatelets (8 $\mathrm{mg})$, carbon black (1 mg) and PVDF (1 mg) were dispersed in $0.2 \mathrm{ml} \mathrm{NMP} \mathrm{to} \mathrm{make} \mathrm{the}$ slurry. This slurry was pasted on two titanium substrates with the area of $\mathrm{cm}^{2}(1 \mathrm{~cm} \times 1 \mathrm{~cm})$ and dried at $60^{\circ} \mathrm{C}$ for $12 \mathrm{~h}$ in air to obtain electrode. The weight of each electrode is about $1 \mathrm{mg}$.

\subsection{Preparation of $G P E$}

GPE was prepared by mixing the solution of polymer blend and sodium salt in different weight ratios. Firstly, $1 \mathrm{~g}$ PVA/ PEO (9:1, wt \%) was dispersed into $10 \mathrm{ml}$ deionized water at $80^{\circ} \mathrm{C}$ and stirring for $8 \mathrm{~h}$ to obtain clear gel solution. Then, different amounts of $\mathrm{CH}_{3} \mathrm{COONa} / \mathrm{Na}_{2} \mathrm{SO}_{4}(50: 50 \mathrm{wt} \%)$ were added in gel polymer solution (table 1). Then, the GPE was stirred for $6 \mathrm{~h}$ to obtain homogeneous gel solution. The maximal weight ratio of polymer blend to sodium salt mixture was $7: 3$ to keep the form of GPE. In the case of higher sodium salt ratios, the gel electrolytes transform to liquid form causing the leaking problem by fabrication of solid-state supercapacitor.

\subsection{Fabrication of testing cells and characterization of electrochemical properties}

The testing cells consist of a commercial reference electrode $\mathrm{Ag} / \mathrm{AgCl}$, a working electrode, a counter electrode and the GPE.

The electrochemical properties of supercapacitor were examined by cyclic voltammetry $(\mathrm{CV})$ from -0.5 to $0.5 \mathrm{~V}$, electrochemical impedance spectroscopy (EIS) in the range of $10 \mathrm{mHz}-10 \mathrm{kHz}$ with $5 \mathrm{mV}$ amplitude, and by galvanostatic charge-discharge with different currents. All these electrochemical investigations were conducted at electrochemical workstation system Zehner Zenium (Z 2.23).
The specific capacitance $\left(C_{\text {cell }}, \mathrm{F} \mathrm{g}^{-1}\right)$ of testing cell was calculated via the following equations [10-13]:

$$
C_{\mathrm{cell}}=\frac{I \times \Delta t}{m \times \Delta V} .
$$

Note that for this condition, the cell used in the calculation includes the active material on electrodes immersing in the GPE.

And the electrode-specific capacitance $\left(C_{\mathrm{s}}, \mathrm{F} \mathrm{g}^{-1}\right)$ was described by the equation:

$$
C_{\mathrm{s}}=4 C_{\text {cell }}
$$

The energy density $\left(E, \mathrm{Wh} \mathrm{kg}^{-1}\right)$ and the power density $\left(P, \mathrm{~W} \mathrm{~kg}^{-1}\right)$ were described in the following equations:

$$
\begin{aligned}
& E=\frac{1}{2} \times \Delta V^{2} \times C_{\text {cell }} \times \frac{1000}{3600}, \\
& P=\frac{E}{\Delta t} \times 3600,
\end{aligned}
$$

where $\Delta V$ is the discharge voltage after $V_{\text {drop }}, I(A)$ the discharge current, $\Delta t(s)$ the discharging time, $m$ the total active material electrode including graphene nanoplatelet, carbon black and PVDF.

The Raman spectrum and XRD pattern of the sample were taken at Raman JOBIN WON, HORIBA and XRD D8 Brucker. The morphology of the sample was observed on scanning electron microscopy (SEM) Hitachi SU8010. The mechanical property of polymer films was tested by microforce testing systems (MTS, Tytron 250). The sample has the dimension of $10 \times 10 \times 0.5 \mathrm{~mm}$ and the testing speed was $5 \mathrm{~mm} \mathrm{~min}^{-1}$.

\section{Results}

Figure 1 shows the Raman spectrum (figure 1a) and XRD pattern (figure 1b) of graphene nanoplatelet/carbon black electrode. The D peak around $1350 \mathrm{~cm}^{-1}$ of carbon bonding and $G$ peak around $1570 \mathrm{~cm}^{-1}$ of phonon vibration of graphite are clearly observed. In addition, the graphene $2 \mathrm{D}$ peak around $2700 \mathrm{~cm}^{-1}$ from second phonon vibration mode is also seen [17]. On the XRD pattern, strong peak at $2 \theta=26.6^{\circ}$ corresponding to the $\mathrm{d}$-spacing between single graphene layers is observed.

Figure 2 shows the SEM image of graphene nanoplatelet/ carbon black electrode. A network-like structure of graphene nanoplatelets is seen. On this network structure of graphene nanoplatelets, carbon black particles or clusters are attached. The attachment of carbon black makes the carbon-based electrode more compact to improve the electrical conductivity of the electrode. 

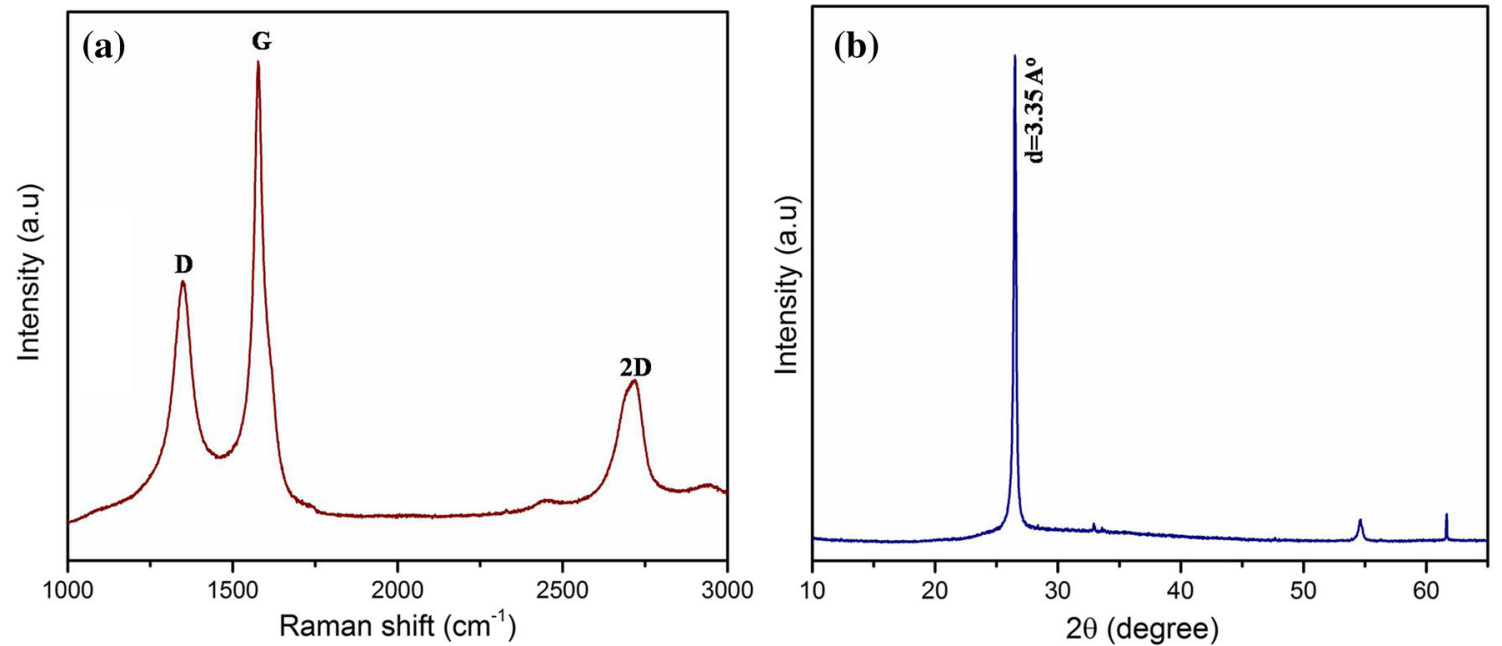

Figure 1. (a) Raman spectrum and (b) XRD pattern of graphene nanoplatelet/carbon black electrode.

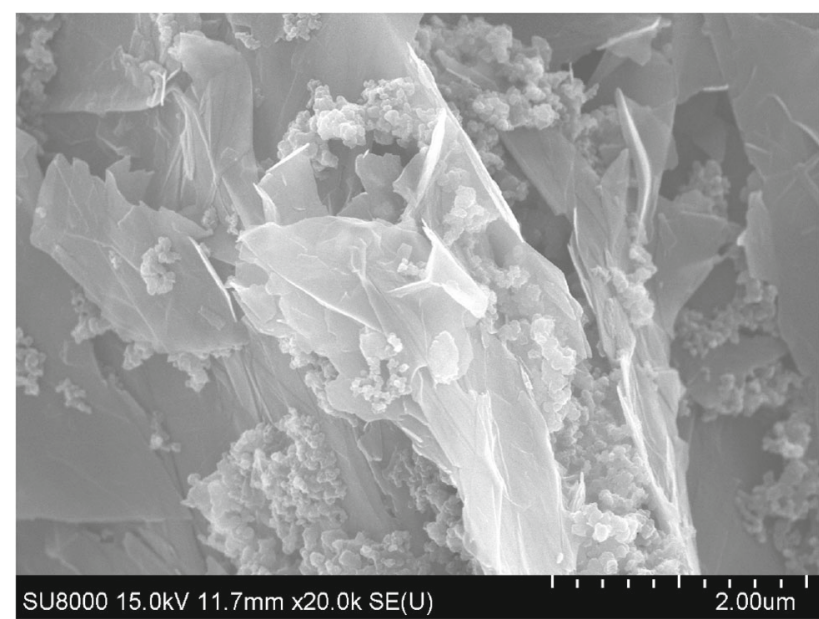

Figure 2. SEM image of graphene nanoplatelet/carbon black electrode.

By the solid-state supercapacitor, the flexibility of the polymer host frame plays an important role. Figure 3 shows the force-displacement diagrams of PEO, PVA, PVA-PEO (9/1) blend. Generally, the elasticity module (E-module) of the sample presents the stiffness of the materials. PVA has the E-module of $2.48 \mathrm{MPa}$ and it is much higher than that of PEO (1.04 MPa). PVA/PEO (9/1) blend has the E-module of about 1.15 MPa. This result indicates that the flexibility of PVA is strongly improved by the PVA/PEO (9/1) blend.

Figure 4a compares the CV curves of supercapacitor with different GPEs at voltage scan rate of $100 \mathrm{mV} \mathrm{s}^{-1}$. The CV curves have good cycles that explain the capacitance is stored energy as double layer capacitance by an agglomeration of ions at interface of electrodes. The increment of $\mathrm{CV}$ curves was coincided with the increasing of sodium salt content

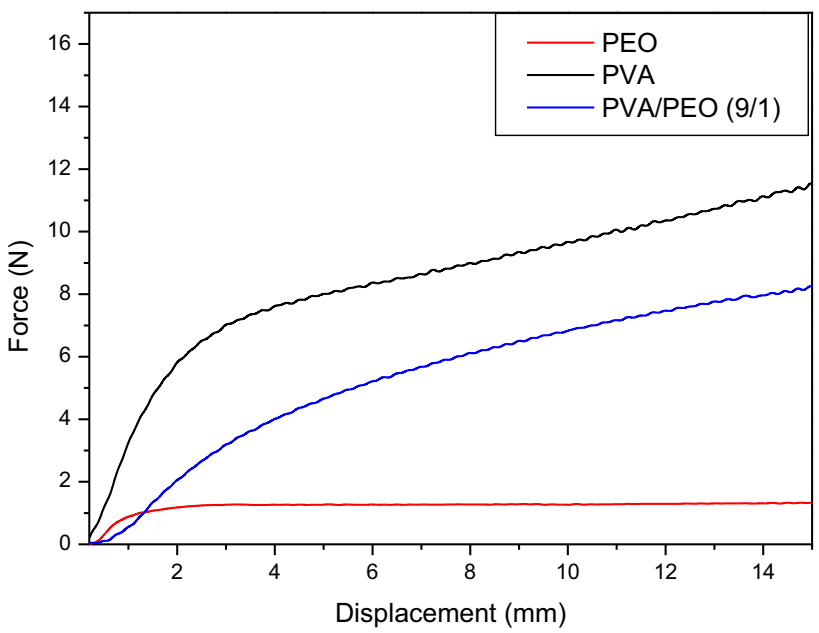

Figure 3. Force-displacement diagrams of PEO, PVA and PVA/PEO (9/1) blend.

in the GPE. Figure 4b, c and d presents the CV curves of supercapacitor with different GPE at different voltage scan rates from 5 to $100 \mathrm{mV} \mathrm{s}^{-1}$. It is clear to see that for all supercapacitors with different GPEs, the current of the supercapacitor increases with increase in voltage scan rate. In addition, area under the CV curves strongly broaden with increase in voltage scan rate.

To investigate the electrochemical behaviour at the electrode/electrolyte interface, EIS measurements were employed. The Nyquist plots of supercapacitors with different GPEs are showed in figure 5. The supercapacitor with the sodium salt mixture of $10 \%$ in GPE presents the highest resistance around $27.04 \Omega$. With increase in sodium salt mixture in the GPE, the resistance of the supercapacitors strongly decreases to 17.3 and $9.94 \Omega$ by the sodium salt mixture of 20 and 30\%, respectively. This result indicates that the ionic 

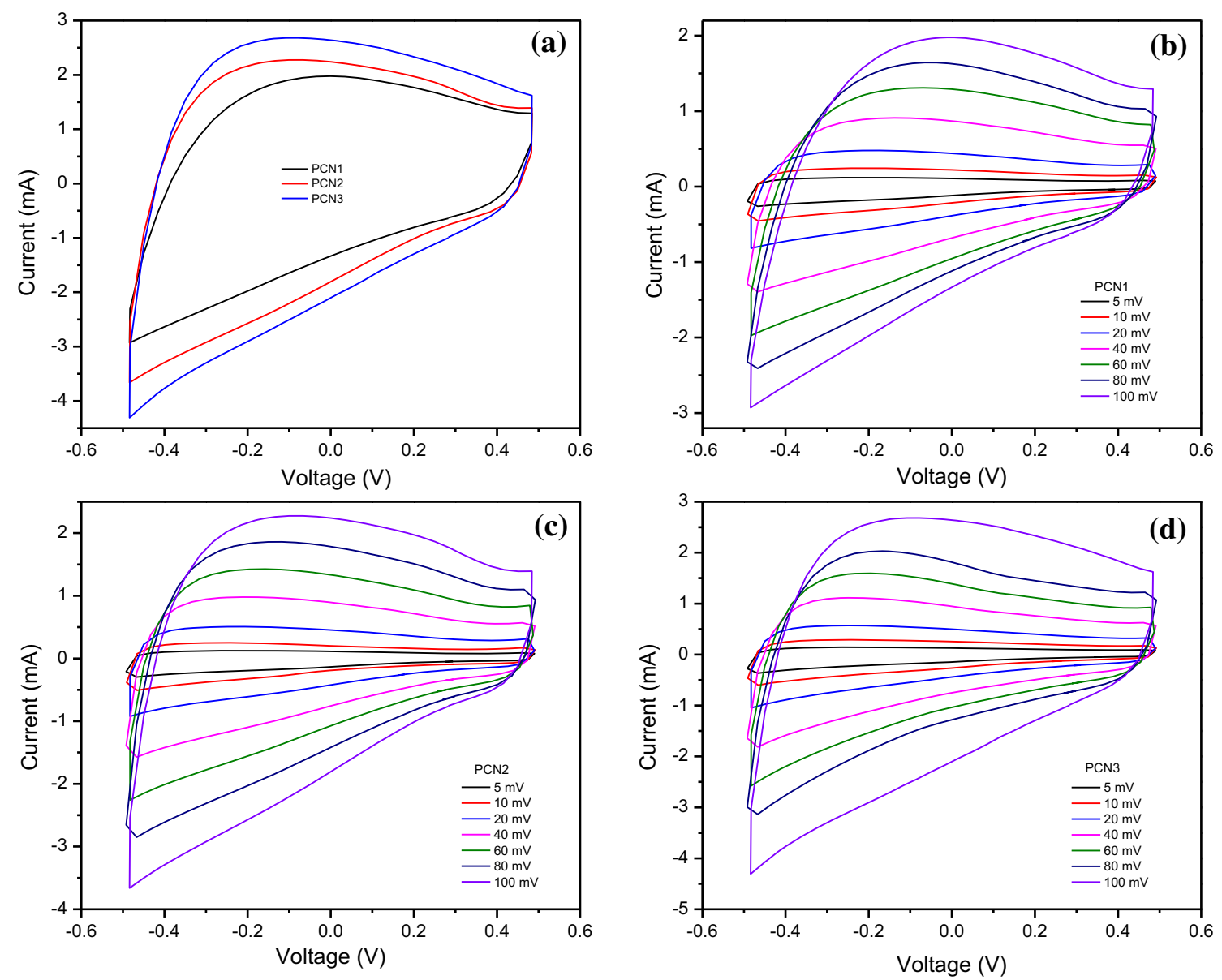

Figure 4. (a) $\mathrm{CV}$ curves of the supercapacitors at voltage scan rate of $100 \mathrm{mV} \mathrm{s}^{-1}$ and $(\mathbf{b}, \mathbf{c}, \mathbf{d}) \mathrm{CV}$ curves of supercapacitors with different GPEs at different voltage scan rates from 5 to $100 \mathrm{mV} \mathrm{s}^{-1}$.

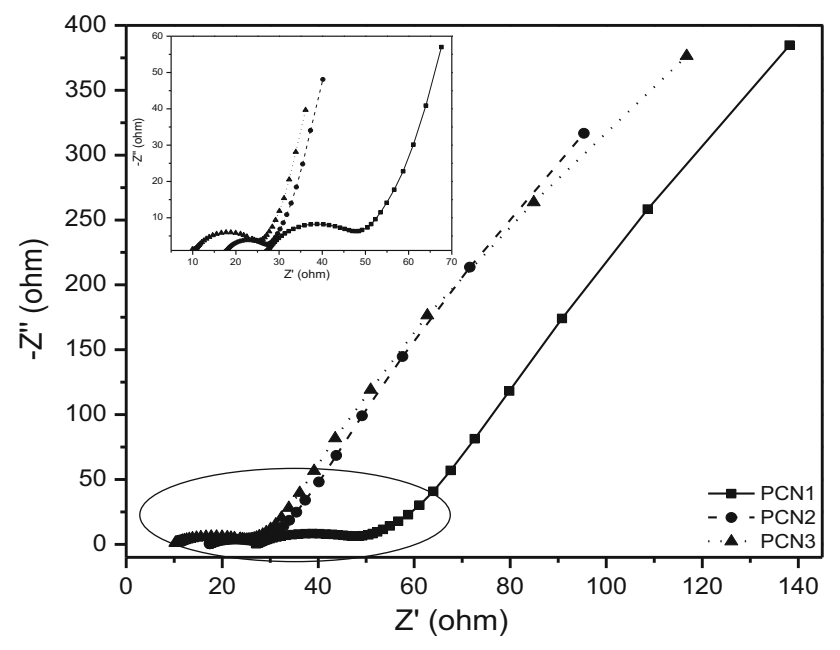

Figure 5. Niquist plots of supercapacitor with different GPEs.

conductivity and the ions transfer in GPE are significantly improved at high content of sodium salt mixture.

Figure 6 shows the galvanostatic charge-discharge curves of supercapacitors with different GPEs at current density of $1 \mathrm{~A} \mathrm{~g}^{-1}$. Although the resistance of supercapacitors with different GPEs decreases with increase in sodium salt content in the GPEs, the charge-discharge time of the supercapacitors do not behave in the same fashion (figure $6 \mathrm{~d}$ ). The reasons for the behaviour of charge-discharge time of the supercapacitor with different GPEs are that the diffusion of ion from gel electrolyte to the electrode is time-dependent. Thus, the time of charge-discharge was not changed suddenly, but the voltage drop of charge-discharge of supercapacitors increases with increase in sodium salt content in the GPE (figure 6d). These factors influence the performance of supercapacitors with different GPEs.

The performance of the supercapacitor is determined according to equations (1)-(4). By the supercapacitor PCN1 at current density of $1 \mathrm{~A} \mathrm{~g}^{-1}$, the electrode specific capacitance, energy density and power density were $91.638 \mathrm{~F} \mathrm{~g}^{-1}$, $3.18 \mathrm{Wh} \mathrm{kg}^{-1}$ and $572.73 \mathrm{~W} \mathrm{~kg}^{-1}$, respectively. By the supercapacitor PCN2 at current density of $1 \mathrm{~A} \mathrm{~g}^{-1}$, the electrodespecific capacitance, energy density and power density were $92.485 \mathrm{~F} \mathrm{~g}^{-1}, 3.211 \mathrm{Wh} \mathrm{kg}^{-1}$ and $578.03 \mathrm{~W} \mathrm{~kg}^{-1}$, respectively. By the supercapacitor PCN3 at current density of $1 \mathrm{~A} \mathrm{~g}^{-1}$, the electrode-specific capacitance, energy density and power density were $93.768 \mathrm{~F} \mathrm{~g}^{-1}, 3.25 \mathrm{Wh} \mathrm{kg}^{-1}$ 

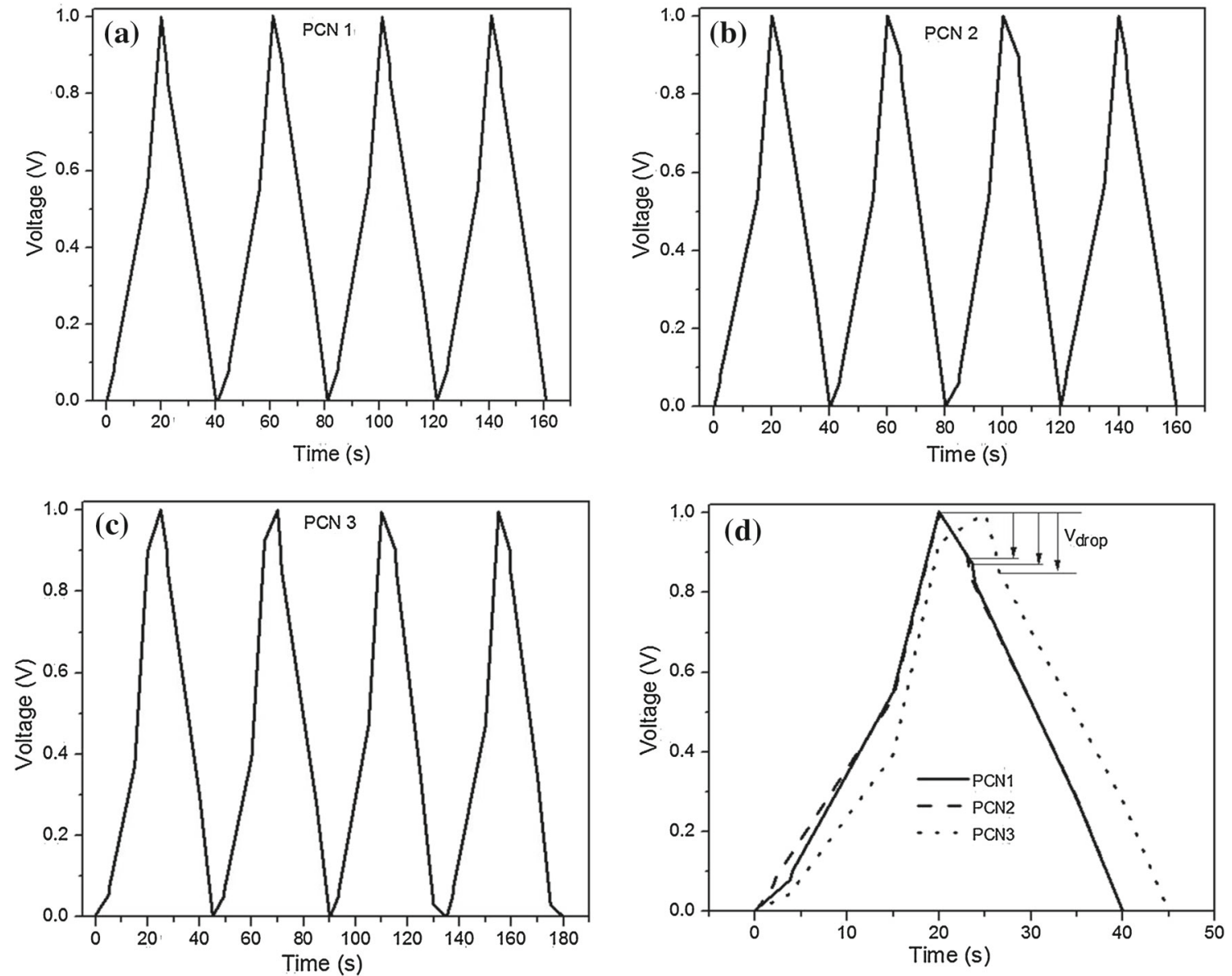

Figure 6. Galvanostatic charge-discharge curves of the supercapacitor at current density of $1 \mathrm{Ag}^{-1}$ : (a) PCN1, (b) PCN2, (c) PCN3 and (d) comparison charge-discharge curves of the supercapacitors with different GPEs at current density of $1 \mathrm{~A} \mathrm{~g}^{-1}$.

and $586.166 \mathrm{~W} \mathrm{~kg}^{-1}$, respectively. The electrochemical properties of the solid-state supercapacitors are slightly increased with increase in sodium salt content in the GPE. One of the reasons for these electrochemical behaviours of the solid-state supercapacitors at different sodium salt contents is the quite-low ion transport in the ionic liquid-based GPE [19].

\section{Conclusions}

The effect of GPE based on PVA/PEO blend and $\mathrm{CH}_{3} \mathrm{COONa/}$ $\mathrm{Na}_{2} \mathrm{SO}_{4}$ mixture on the performance of double layer supercapacitor was investigated. The results reveal that the sodium salt mixture was easily dispersed in the PVA/PEO blend gel until $30 \%$. The performance of supercapacitor was significantly improved by increasing the sodium salt mixture content in the GPE. At the sodium salt content of $30 \%$, the supercapacitor showed the good energy density of $3.25 \mathrm{Wh} \mathrm{kg}^{-1}$ and power density of $586.166 \mathrm{~W} \mathrm{~kg}^{-1}$. These results suggest that the sodium salt-based GPE is promising environmental gel electrolyte for double layer supercapacitor with low-cost and it is easy to fabricate.

\section{Acknowledgements}

We acknowledge the financial support from the Institute of Chemistry, Vietnam Academy of Science and Technology (VHH.2017.1.02).

\section{References}

[1] Xihong L, Minghao Y, Gongming W, Yexiang T and Yat L 2014 Energy Environ. Sci. 72160

[2] Cheng Z, Yida D, Wenbin H, Jinli Q, Lei Z and Jiujun Z 2015 Chem. Soc. Rev. 447484

[3] Choudhury N A, Sampath S and Shukla A K 2009 Energy Environ. Sci. 255

[4] Béguin F, Presser V, Balducci A and Frackowiak E 2014 Adv. Mater. 262219 
[5] Sharma P and Bhatti T S 2010 Energy Convers. Manag. 51 2901

[6] Patrice S and Yury G 2008 Nat. Mat. 7845

[7] Gongming W, Xihong L, Yichuan L, Teng Z, Hanyu W, Yexiang T et al 2012 ACS Nano 1110296

[8] Jagadage A D, Kumbhar V S, Dhawale D S and Lokhande C D 2013 Electrochim. Acta 9832

[9] Senthilkumar S T, Kalai Selvan R, Ponpandian N and Melo J S 2012 RSC Adv. 28937

[10] Xing Z, Liangliang W, Jing P, Pengfei C, Xiaosheng C, Jiuqiang L et al 2015 Adv. Mater. Interface 215

[11] Haijun Y, Leqing F, Jihuai W, Youzhen L, Miaoliang H, Jianming L et al 2012 RSC Adv. 26736

[12] Meng C, Liu C, Chen L, Hu C and Fan S 2010 Nano Lett. 10 4025
[13] Boschin A and Johansson P 2015 Electrochim. Acta 175 124

[14] Bhargav P B, Mohan V M, Sharma A L and Rao V V R N 2009 Curr. Appl. Phys. 9165

[15] Kumar K K, Ravi M, Pavani Y, Bhavani S, Sharma A K and Rao V V R N 2014 J. Memb. Sci. 454 200

[16] Wu C H, Wang C H, Lee M T and Chang J K 2012 J. Mater. Chem. 2221466

[17] Zhu Z, Jiang H, Guo S, Cheng Q, Hu Y and Li C 2015 Sci. Rep. 515936

[18] Boris D, Volker P, Min H, Maria R L, Majid B and Yurg G 2013 ChemSusChem. 61

[19] Pandey G P, Kumar Y and Hashmi S A 2010 Ind. J. Chem. 49A 743 